\title{
Job Expectations of Students Graduating from Agricultural and Horti- cultural School
}

\author{
Ann Verspecht, Dirk Van Lierde and Nicole Taragola \\ Ministry of the Flemish Community \\ Centre for Agricultural Economics (CAE) \\ Treurenberg $164^{\text {th }}$ floor \\ 1000 Brussels \\ Belgium
}

Keywords: education, graduate students, job objectives, horticulture, continuance

\begin{abstract}
In Flanders a survey was organized in the agricultural and horticultural schools. In this survey the graduate students were questioned on what their expectations are for their professional life. Asked for their intention in the immediate future it was remarkable that $36 \%$ of the graduate students had the intention to continue school. Of the students that will not continue their studies $17 \%$ will work on the parental holding; this is $29 \%$ of the students whose parents are entrepreneurs. Only $10 \%$ of the graduates will start a new holding immediately after they finish school. In the long term $21 \%$ of the graduate students want to take over the holding of their parents, $24 \%$ want to start a brand new enterprise. This means that almost $50 \%$ of the graduate students want to become an entrepreneur one day. Of these future entrepreneurs $45 \%$ will manage an agricultural holding, $15 \%$ will manage a horticultural holding, $23 \%$ a landscape gardening holding and the other $17 \%$ will manage another kind of holding. To maintain the number of holdings in Flanders 475 agricultural and 138 horticultural new holdings are needed every year. According to the study only 207 and 69 new entrepreneurs are available; this is not enough to replace all the holdings that disappear. On the other hand new holdings are larger than the average holding; to keep the total production potential of the sector less new holdings are required. For the graduate students the most important criterion for a job is a good income. On the second place, but very close to the first one is the expectation that the job would offer a varied work. To attract more future entrepreneurs it is necessary to improve the image of the sector.
\end{abstract}

\section{INTRODUCTION}

In Flanders, the Dutch speaking part of Belgium, horticulture has an important role in agriculture. Research indicated that in the future the size of horticultural holdings will increase in order to become more competitive (Verspecht et al., 2003).This means that on the holdings, that will be larger than today, there will be a need for qualified workers. Furthermore it appears from data of the agricultural census that a high percentage of the young entrepreneurs have had an agricultural education. $75 \%$ of the entrepreneurs younger than 36 years have had an agricultural education. This means that in the future there will be a growing need for qualified people. But are there enough students in the agricultural and horticultural schools who want to start an own enterprise or are prepared to work on horticultural holdings? 
The aim of this study was to examine for the year 2002 how many of the students graduating from Flemish agricultural and horticultural schools were thinking of starting a holding in the future and how many were thinking of working as a paid worker on horticultural holdings. Furthermore it was studied what was attractive in a job for these graduates.

\section{MATERIAL AND METHOD}

In order to obtain a better insight of the future potential of new entrepreneurs and skilled workers a survey was organized in the Flemish agricultural and horticultural schools. In this survey the graduate students, or last year students, were questioned on their professional future; what were their expectations for their professional life. The survey was done in the month of May, at the end of the school year. The questionnaires were filled in, in the classroom and then send to the Centre of Agricultural Economics where they were analyzed.

About $80 \%$, or 812, of the graduates in the Flemish agricultural and horticultural schools participated in this 2002 survey. In Flanders the agricultural and horticultural education is divided into four study levels:

- vocational training: the graduates are normally 18 years old, the accent is on practical work.

- technical school: the graduates are normally 18 years old, accent is on practical work and theory

- "graduaat" in agriculture: the graduates are normally 20 years old, accent is on theory. This can be compared with bachelor studies.

- high school: the graduates are normally 22 years old

After finishing the technical school one can continue with the "graduaat" study, and after the "graduaat" study one can continue with high school. The last year students that belonged to one of these four study levels were questioned. There is also a fifth level of studies, the university level. These students however were not involved in this study.

It was remarkable that only one third of these students had parents that run an agricultural or horticultural holding, or run a landscape gardening holding (table 1). In total there are $26 \%$ of the students that come from an agricultural holding, $6 \%$ come from a horticultural holding and $2 \%$ came from a landscape gardening holding. The part of students coming from agricultural or horticultural holdings increased with increasing level of study; from $28 \%$ in the vocational training to $52 \%$ for high school graduates. In total 19 $\%$ of the graduate students were female students, the percentage of female students increased with increasing level of study; from $17 \%$ in the vocational training to $37 \%$ for high school graduates (table 2).

\section{RESULTS AND DISCUSSION}

\section{What are the professional plans of the graduates for the immediate future?}

Asked after their intention immediately after their studies it was remarkable that $36 \%$ of the graduate students had the intention to continue school (table 3). In the vocational training there are one third of the students that will continue school, in the technical school $60 \%$ want to continue studies. $17 \%$ of the graduates in agriculture and $10 \%$ of the high school students want to continue their studies. $35 \%$ of the male students will continue their studies against $41 \%$ of the female students. From all the students that want to continue their studies about $70 \%$ will choose a branch of studies that is related with the 
agricultural or horticultural sector; $14 \%$ of the students did not know yet what kind of studies they will choose. $31 \%$ of the students which parents are agricultural or horticultural entrepreneurs will continue their studies.

$10 \%$ of the graduate students will work on the parental holding; this is $29 \%$ of the students whose parents are entrepreneurs. Only $6 \%$ of the graduates have the intention to start a new holding immediately after they finish school; the parents of $40 \%$ of them already have a holding. Only $4 \%$ of the graduate students want to work as a wage worker on a horticultural holding and $10 \%$ want to work as a wage worker on a landscape gardening holding.

From the graduate students $18 \%$ want to work as a wage earner in supply companies for agriculture and horticulture. Only $13 \%$ of the graduates will immediately after they finish school work in a sector that is not related to agriculture or horticulture.

It is remarkable that from the $64 \%$ of graduates that will not continue their studies, almost $49 \%$ declare that they already have a job after they will finish their studies. It are especially the graduates of the technical school (78 \%) and of the vocational training (55 $\%)$ that already have a job. Only $29 \%$ of the 'graduaat' students and $6 \%$ of the high school students declare that they already have a job.

Of the graduates that will not continue their studies $51 \%$ of the male students declare that they will have a job, only $26 \%$ of the female students have the same prospects.

\section{What are the professional plans of the graduates in the future?}

In the long run the professional intention of the graduates is a little bit different (table 4). In the future $21 \%$ of the graduate students want to take over the holding of their parents. This means that $58 \%$ of the students whose parents have a holding have the intention to take over this holding one day. Two third of the vocational students and $72 \%$ of the technical school students, whose parents have a holding, want to take over this holding in the future. Of the "graduaat" students $43 \%$ will do so, and of the high school students only $10 \%$ will take over the parental holding.

There are more graduate students that want to start a new holding in the future, $24 \%$ of them want to do so. About $25 \%$ of these students have parents that have a holding, but they prefer to start an own brand new enterprise.

Of the new entrepreneurs $15 \%$ will lead a horticultural holding, and $44 \%$ of these will take over the parental holding and $56 \%$ will start a new holding (table 5 ). $45 \%$ of the new entrepreneurs think that they will lead an agricultural holding in the future, $78 \%$ of them will take over the parental holding and $22 \%$ will lead a new agricultural holding. There will be 23 pct of the new entrepreneurs that will have a landscape gardening enterprise, $92 \%$ of them will lead a new holding. Finally there will be $17 \%$ that will lead another kind of holding, $80 \%$ of them will lead a brand new holding and only $20 \%$ will take over the parental holding.

Of the graduate students only $5 \%$ want to work as a wage worker in the horticultural sector, $7 \%$ will work as a wage worker in the landscape gardening sector and the other 43 $\%$ want to work in another sector.

\section{Continuance of the sector}

When the data of the survey of 818 graduate students are extrapolated to the population of 1.020 graduate students one can conclude that from the 2002 graduate students there are 460 candidate future entrepreneurs. 69 will be entrepreneur of a horticultural 
holding, 207 of an agricultural holding, 108 of a landscape gardening holding and 76 of another kind of holding. In Flanders there are 5.500 specialised horticultural holdings and 19.000 agricultural holdings. Supposing that a career lasts 40 years this means that there is a yearly need for about 138 new horticultural entrepreneurs and 475 new agricultural entrepreneurs. This figures are more than twice the number of extrapolated new entrepreneurs. According to this hypothesis this means that the continuance of the sector is not assured. In fact the number of horticultural and agricultural farms is decreasing. Between 1990 and 2000 the number of horticultural holdings decreased with $18 \%$ but the total production potential, measured in standard gross margins, increased with 8,5 \% (Verspecht et al., 2003; Van Lierde and Taragola, 2000). In agriculture the total production potential decreased in the same period with $2 \%$, the number of holdings decreased with $22 \%$. The size of the average holding is growing. This means that if the intention is to keep the production potential on the same level it is not necessary that all the entrepreneurs that stop their activities are replaced by new ones. The new holdings are generally spoken greater than the average ones, so the production potential can be kept at the same level with fewer newcomers. Although the number of new possible candidate entrepreneurs is much lower than the number required if one wants to keep the number of entrepreneurs unchanged, it is not impossible that it is high enough to keep the production potential unchanged.

\section{Objectives which are important for the graduate students in the choice of a job}

In order to know what graduate students expect from their future job a question was added in the survey. In this question seven objectives were given that might influence the choice of a job, the students had to order them starting with the most important objective till the objective that was of the least importance to them. This kind of questions limit the possibilities of statistical treatment, the weight of the first place is not seven time the weight of the seventh choice (De Pelsmaecker and Van Kenhove, 1999). But these kinds of questions can give an indication on the opinion of the questioned students.

According to researchers in the domain of work motivation (MOW International Research Team, 1987) different aspects are important in a job. The MOW team, or Meaning Of Working team, is an international research team that studies the meaning and value of working for individuals and relevant groups in the society. There are instrumental objectives (a good income, extra legal advantages,...), intrinsic objectives (an interesting job, working with plants and animals,...) expressive objectives (the possibility to develop ones capacities, to make a career,...) and social objectives (social contacts with other people,...). Some of these objectives were taken into account in the question (table 6).

From the answers it was clear that the graduate students prefer first of all a good income. $33 \%$ of the students put this on the first place, $24 \%$ on the second and $17 \%$ on the third place. Varied work came on the second place; $26 \%$ of the students put this on the first place, $23 \%$ on the second place and $18 \%$ on the third place. The other possible choices were far behind. Personal independence and self-reliance came on the third place followed by working with plants and animals, career possibilities, taking up responsibility, and finally fixed hours. It was remarkable that the students considered that 'fixed hours' was less important for them.

There were some differences between the male students and the female students. The choice for a good income is slightly higher for the male students; the female students put working with plants and animals on the third place. 
When one analyses the answers of the students that want to have their own holding in the future, one can see that these youngsters also put a good income on the first place. Varied work also comes on the second place but there are fewer students that put this choice on the first place (20\%) The future entrepreneurs find that independence and selfreliance are important, $19 \%$ put this objective on the first place, this is more than the figures from the average student.

There are also differences between the students of the different study levels. The graduate students of the vocational training and the technical school attach great interest to a good income. $50 \%$ of the vocational training graduates and $30 \%$ of the technical school graduates put this objective on the first place. For the "graduaat" students however a varied work comes on the first place for $38 \%$ of the students, only $14 \%$ of the students put a good income on the first place. For the high school students varied work is the most important objective, $58 \%$ put this objective on the first place. Working with plants and animals comes on the second place, $21 \%$ of the students put this on the first place. It is remarkable that no one of the high school graduates put a good income on the first place. Also remarkable is that they attach little importance to fixed hours, $68 \%$ of these students put this on the seventh place.

These results are comparable with the results from the MOW International Research Team. They found that globally a good income was the most important job aspect. But there were differences in the appreciation of different job objectives that were dependent on the study level and the sex of the workers. People with less education and men are less instrumental oriented than people with a higher study level and women. An explanation can be that people with a higher study level can expect a higher wage, so they can emphasize on intrinsic aspects of the job. This can also be explained by the pyramid of needs of Maslow (1954). According to this theory everyone tries to reach a higher level of needs when the lower needs are already satisfied. First of all there are primary needs (income), second comes the need of security and safety (social security), third comes the need of social acceptation, fourth the need of appreciation and status and fifth comes the need of self development (achieving creative performances, grow and development in the job).

\section{What does the sector think about this?}

Different actors of the sector were interviewed. In total 30 people were interviewed, they were the technical advisors representing all the banks that are important for agricultural credits, extension officers, representatives of auctions and experimental stations and also some growers. They were interviewed on the basis of a limited number of questions, and they could give their answers and comments on these questions. It appears that they still believe in the future of the horticultural sector in Flanders. But the sector has not a good image. The bad image of the sector urge parents (especially parents with an agricultural or horticultural holding) to send their children to other schools than agricultural or horticultural schools. This leads to fewer students in the agricultural and horticultural schools and it discourages young people to make a choice for a career in these sectors.

The different actors in the sector find that the schools should have more contacts with the enterprises, and that they would have to take care that the education follows the developments in the sector. They also say that schools will have to give more lessons on accountancy and on economics in order to prepare their students to become entrepreneurs. The sector also will have to make efforts to improve its image, an image that suffers from the pessimism in the sector itself. Few of the young people will be tented to find a future 
in a sector with a less good image. If the image of the sector would be better there will be more students in agricultural and horticultural schools, and more young people will be attracted to a career as entrepreneur.

\section{CONCLUSIONS}

The agricultural and horticultural studies in Flanders offer perspectives to become an entrepreneur. Almost $50 \%$ of the graduate students have the intention to become an entrepreneur. Children of farmers and horticultural entrepreneurs in majority want to succeed their parents on the farm or horticultural holding. This is especially the case on agricultural holdings. This make sense as in Flanders farming land is very scarce. If the sector wants to keep the number of holdings unchanged then there are not enough candidate entrepreneurs that study in agricultural and horticultural schools. On the other hand the future holdings will be larger than the actual average holding, so the production potential of the sector can be maintained with fewer new entrepreneurs.

If one wants to attract more students in the agricultural and horticultural schools, and thus more potential future entrepreneurs, the education must be more attractive and there is a need for a better image of the sector. This should attract more children of agricultural and horticultural entrepreneurs. To make the profession of paid worker in the horticultural sector more attractive the wages must be at the same level of other economical sectors and the work must be more varied.

Agricultural and horticultural education offer good prospects for a job. Of the students that will not continue their studies 50 \% declare that they already have a job after they finish school.

This study only deals with one year and just gives a random indication of the situation. To have a better insight in the issue further research is necessary.

\section{Literature Cited}

De Pelsmaecker, P. and Van Kenhove, P. 1999. Marktonderzoek: methoden en toepassingen. Garant, Leuven.

MOW International Research Team. 1987. The meaning of working. Academic Press, Harcourt Brace Jovanovich Publishers.

Maslow, A.H. 1954. Motivation and personality. Hasper and Row, New York

Van Lierde, D. and Taragola, N. 2000. Structuur van de Belgische tuinbouwbedrijven in 1999. Centrum voor Landbouweconomie, Brussel.

Verspecht, A., Van Lierde, D. and Taragola, N. 2003. Optimale schaalgrootte van de Vlaamse glastuinbouwbedrijven. Centrum voor Landbouweconomie, Brussel.

Verspecht, A, Van Lierde, D. and Vandenbossche, A. 2003. Arbeidsproblematiek in de Vlaamse glastuinbouw. Centrum voor Landbouweconomie, Brussel. 
Table 1. Number of students by study level and the profession of the parents

\begin{tabular}{|l|r|r|r|r|r|}
\hline $\begin{array}{l}\text { Profession of the } \\
\text { parents }\end{array}$ & \multicolumn{6}{|c|}{ Study level } \\
\cline { 2 - 7 } & $\begin{array}{l}\text { Vocational } \\
\text { training }\end{array}$ & $\begin{array}{l}\text { Technical } \\
\text { school }\end{array}$ & “Graduaat” & High school & Total \\
\hline Agriculture & 85 & 62 & 61 & 7 & 215 \\
\hline Horticulture & 24 & 18 & 8 & 3 & 53 \\
\hline $\begin{array}{l}\text { Landscape } \\
\text { gardening }\end{array}$ & 3 & 8 & 3 & 0 & 14 \\
\hline Other holding & 5 & 4 & 4 & 0 & 13 \\
\hline Other profession & 265 & 135 & 102 & 9 & 511 \\
\hline Not known & 9 & 3 & 0 & 0 & 12 \\
\hline Total & 391 & 230 & 178 & 19 & 818 \\
\hline
\end{tabular}

Table 2. Number of male students and female students by study level

\begin{tabular}{|l|r|r|r|}
\hline Study level & Male students & Female students & Total \\
\hline Vocational training & 324 & 67 & 391 \\
\hline Technical school & 200 & 30 & 230 \\
\hline “Graduaat” & 129 & 49 & 178 \\
\hline High school & 12 & 7 & 19 \\
\hline Total & 665 & 153 & 818 \\
\hline
\end{tabular}

Table 3. Profession that graduate students want to practise immediately after the ending of their studies

\begin{tabular}{|l|r|r|r|r|r|}
\hline $\begin{array}{l}\text { Profession immediate after the } \\
\text { ending of the studies }\end{array}$ & \multicolumn{5}{|c|}{ Study level } \\
\cline { 2 - 6 } & $\begin{array}{l}\text { Voca- } \\
\text { tional }\end{array}$ & $\begin{array}{l}\text { Technical- } \\
\text { school }\end{array}$ & Graduaat & $\begin{array}{c}\text { High } \\
\text { school }\end{array}$ & Total \\
\hline Working on the parental holding & 42 & 27 & 18 & 0 & 87 \\
\hline $\begin{array}{l}\text { Paid employment on a horticul- } \\
\text { tural holding }\end{array}$ & 24 & 7 & 5 & 0 & 36 \\
\hline $\begin{array}{l}\text { Paid employment on a land- } \\
\text { scape gardening holding }\end{array}$ & 52 & 19 & 10 & 0 & 81 \\
\hline Starting a new holding & 32 & 9 & 11 & 1 & 53 \\
\hline Continuing studies & 121 & 138 & 31 & 2 & 292 \\
\hline $\begin{array}{l}\text { Other profession within the sec- } \\
\text { tor }\end{array}$ & 34 & 17 & 80 & 16 & 147 \\
\hline Profession outside the sector & 78 & 13 & 14 & 0 & 105 \\
\hline Not known & 8 & 0 & 9 & 0 & 17 \\
\hline Total & 391 & 230 & 178 & 19 & 818 \\
\hline
\end{tabular}


Table 4. Final job that graduates want to do by study level

\begin{tabular}{|l|r|r|r|r|r|}
\hline Final job graduates want to & \multicolumn{5}{|c|}{ Study level } \\
\cline { 2 - 6 } do by study level & $\begin{array}{l}\text { Voca- } \\
\text { tional } \\
\text { training }\end{array}$ & $\begin{array}{l}\text { Technical } \\
\text { school }\end{array}$ & Graduaat & $\begin{array}{l}\text { High } \\
\text { school }\end{array}$ & \multicolumn{1}{l|}{ Total } \\
\hline Taking over parental holding & 71 & 66 & 33 & 1 & 171 \\
\hline $\begin{array}{l}\text { Work for a horticultural } \\
\text { holding }\end{array}$ & 28 & 11 & 1 & 0 & 40 \\
\hline $\begin{array}{l}\text { Work for a landscape gar- } \\
\text { dening holding }\end{array}$ & 37 & 18 & 6 & 0 & 61 \\
\hline Starting a new holding & 106 & 55 & 34 & 2 & 197 \\
\hline $\begin{array}{l}\text { Other professional occupa- } \\
\text { tion }\end{array}$ & 145 & 78 & 99 & 15 & 337 \\
\hline Not known & 4 & 2 & 5 & 1 & 12 \\
\hline Total & 391 & 230 & 178 & 19 & 818 \\
\hline
\end{tabular}

Table 5. Number of graduates taking over a holding or starting a new holding by study level

\begin{tabular}{|c|r|r|r|r|r|}
\hline \multirow{2}{*}{$\begin{array}{l}\text { Taking over or starting } \\
\text { a new holding }\end{array}$} & \multicolumn{6}{|c|}{ Study level } \\
\cline { 2 - 6 } & $\begin{array}{l}\text { Voca- } \\
\text { tional }\end{array}$ & $\begin{array}{l}\text { Technical } \\
\text { school }\end{array}$ & Graduaat & $\begin{array}{l}\text { High } \\
\text { school }\end{array}$ & \multicolumn{1}{l|}{ Total } \\
\hline Horticultural holding & 20 & 18 & 16 & 1 & 55 \\
\hline Taking over & 9 & 10 & 5 & 0 & 24 \\
\hline New holding & 11 & 8 & 11 & 1 & 31 \\
\hline Agricultural holding & 76 & 54 & 34 & 2 & 166 \\
\hline Taking over & 56 & 48 & 24 & 1 & 129 \\
\hline New holding & 20 & 6 & 10 & 1 & 37 \\
\hline Landscape gardening & 48 & 29 & 9 & 0 & 86 \\
\hline Taking over & 2 & 5 & 0 & 0 & 7 \\
\hline New holding & 46 & 24 & 9 & 0 & 79 \\
\hline Other holding & 33 & 19 & 9 & 0 & 61 \\
\hline Taking over & 4 & 3 & 5 & 0 & 12 \\
\hline New holding & 29 & 16 & 4 & 0 & 49 \\
\hline Total & 177 & 120 & 68 & 3 & 368 \\
\hline
\end{tabular}

Table 6. Objectives that are important for graduates when they choose a job

\begin{tabular}{|c|c|c|c|c|c|c|c|}
\hline $\begin{array}{l}\begin{array}{l}\text { Order of choice } \\
\text { (in percent) }\end{array} \\
\text { Objective }\end{array}$ & $\begin{array}{l}1^{\text {st }} \\
\text { choice } \\
\%\end{array}$ & $\begin{array}{l}2^{\mathrm{d}} \\
\text { choice } \\
\%\end{array}$ & $\begin{array}{l}3^{\text {th }} \\
\text { choice } \\
\%\end{array}$ & $\begin{array}{l}4^{\text {th }} \\
\text { choice } \\
\%\end{array}$ & $\begin{array}{l}5^{\text {th }} \\
\text { choice } \\
\%\end{array}$ & $\begin{array}{l}6^{\text {th }} \\
\text { choice } \\
\%\end{array}$ & $\begin{array}{l}7^{\text {th }} \\
\text { choice } \\
\%\end{array}$ \\
\hline A good income & 33 & 24 & 17 & 9 & 5 & 6 & 2 \\
\hline Varied work & 26 & 23 & 18 & 13 & 8 & 5 & 1 \\
\hline $\begin{array}{l}\text { Personal independ- } \\
\text { ence and self-reliance }\end{array}$ & 12 & 10 & 15 & 16 & 19 & 17 & 7 \\
\hline $\begin{array}{l}\text { Working with plants } \\
\text { and animals }\end{array}$ & 10 & 10 & 10 & 9 & 14 & 18 & 24 \\
\hline Career possibilities & 8 & 12 & 14 & 16 & 16 & 18 & 11 \\
\hline Taking responsibility & 5 & 11 & 14 & 22 & 22 & 15 & 6 \\
\hline Fixed hours & 4 & 6 & 8 & 9 & 10 & 14 & 43 \\
\hline
\end{tabular}

